\title{
АКТУАЛЬНІСТЬ ОРГАНІЗАЦІЇ ЕФЕКТИВНОЇ САМОСТІЙНОЇ РОБОТИ СТУДЕНТІВ ПРИ ВИВЧЕННІ ФАРМАКОЛОГІЇ
}

\author{
S. Yu. Chechotina, R. V. Lutsenko, T. O. Deviatkina, E. H. Kolot, A. H. Sydorenko \\ Ukrainian Medical Dental Academy, Poltava \\ THE RELEVANCE OF EFFECTIVE STUDENTS' INDIVIDUAL WORK \\ DURING PRACTICAL TRAINING OF PHARMACOLOGY
}

\begin{abstract}
Анотація. У статті проаналізовано динаміку розподілу навчального навантаження з дисципліни «Фармакологія» в період підготовки студентів 2-3 курсів стоматологічного та 3 курсу медичного факультетів. Розкрито актуальність раціональної організації самостійної роботи студентів при вивченні дисципліни у зв’язку зі зменшенням кількості аудиторних годин. Представлено порівняльну характеристику кількості аудиторних та позааудиторних годин з фармакології за фахом «Стоматологія» та «Лікувальна справа» згідно з робочими програмами. Встановлено, що за останні 3-4 навчальні роки кількість годин для практичних занять у студентів, які навчалися за освітньо-кваліфікаційним рівнем «Спеціаліст», скоротилася в 1,6 раза у студентів стоматологічного факультету та в 1,8 раза у студентів медичного факультету зі збереженням загальної кількості годин із дисципліни. 3 переходом підготовки спеціалістів другого (магістерського) рівня вищої освіти ситуація дещо покращилась. Однак у студентів медичного факультету згідно з новою типовою програмою перелік лікарських препаратів збільшено майже наполовину та обсяг позааудиторних годин більше на 15 \% порівняно зі студентами-стоматологами. Для оптимізації вивчення «Фармакології» та раціональної організації самостійної роботи студентів викладачами кафедри підготовлено достатнє методичне забезпечення, видано навчальні підручники та посібники, залучаються інноваційні технології та інтерактивні форми навчання.
\end{abstract}

Ключові слова: самостійна робота студентів; фармакологія; навчальне навантаження.

Abstract. The article is concerned with the dynamics of course schedule on Pharmacology during the practical training of 2nd 3rd years students of dental faculty and 3rd ones - medical faculty. The relevance of the organization of students' individual work is analyzed and indentified. It is concerned with the decreased number of hours of practical courses. Comparative characteristics of in-classes learning and out classes activities on academic discipline of Pharmacology by Dentistry and Medicine specialty according to the schedule is presented. It has been indicated, that the amount of hours for practical classes for students who studied by Specialist Degree decreased in 1.6 in students of dental faculty and in 1.8 - in medical ones. The total number of hours was saved. With the change of specialists' training of Master's Degree of high school, the situations has been improved. According to new schedule in medical students, the list of drugs increased in half of the total number of hours and the number of out-classes hours - on $15 \%$ compared with dental students. Methodical recommendations and instructions were prepared by instructors to optimize the study the discipline of Pharmacology. Textbooks, manuals, innovative technologies and methods of interactive learning are involved.

Key words: students' individual work; Pharmacology; teaching load.

(ㄷ С. Ю. Чечотіна, Р. В. Луценко, Т. О. Дев’яткіна та ін. 
Вступ. Відповідно до Положення про організацію навчального процесу у вищих навчальних закладах, самостійна робота студента (СРС) є основною формою засвоєння студентом навчального матеріалу в час, вільний від обов'язкових навчальних занять. Згідно з принципами трансферної системи, здатність до «самостійного» навчання $€$ необхідною складовою загальної компетенції студента. Проблема формування навичок до самостійної роботи в умовах особистісно орієнтованого навчання $\epsilon$ актуальною і ключовою в стратегічних напрямах якісної системи підготовки медичних кадрів у закладах вищої освіти МОЗ України. Роль самопідготовки студентів набула особливого значення в зв' язку з упровадженням у національний освітній процес вищої школи нових стандартів освіти, що не зовсім виправдано: насамперед це стосується скорочення практичних занять 3 основ пропедевтичної фармакології, яка викладається протягом двох навчальних семестрів і закладає підгрунтя для засвоєння клінічної фармакології й інших клінічних дисциплін [6].

Тому постає необхідність постійно раціоналізувати навчальний процес шляхом удосконалення змісту, форм і методів навчально-пізнавальної діяльності студентів закладів вищої освіти, що якнайкраще сприятиме розвитку і формуванню у них творчих здібностей [3]. При обмеженні навчального аудиторного часу, а також з урахуванням психологічних особливостей студента, виникає необхідність збільшувати позааудиторний час навчання [3].

У формуванні практичних навичок першочергове значення має рання мотивація студентів, яка формується під час індивідуальної або колективної діяльності, під керівництвом, але при відсутності викладача в спеціально відведений для цього аудиторний і позааудиторний час. Під час аудиторної роботи відбувається традиційне засвоєння основної освітньої програми згідно з навчально-тематичними планами, шляхом відвідування практичних занять, лекцій, семінарів тощо. Останнім часом все більше академічних годин відводиться на індивідуальну СРС у позааудиторний час [2].

Мета статті - проаналізувати динаміку розподілу аудиторних та позааудиторних годин (навчального навантаження) з дисципліни «Фармакологія» в період підготовки студентів 2-3 курсів стоматологічного та 3 курсу медичного факультетів для оцінки ефективності організації навчального процесу.

Теоретична частина. Самостійна робота - це вид навчальної діяльності, що виконується сту- дентом при відсутності контакту з викладачем або керований викладачем опосередковано через спеціальні навчальні матеріали. У підготовці майбутніх фахівців самостійна робота виконує низку важливих виховних і освітніх функцій: розвивальну, що сприяє підвищенню культури розумової праці, тренуванню когнітивних здібностей студентів; інформаційно-навчальну, що активізує професійну ерудицію та вміння працювати з великим об’ємом інформації; орієнтувальну і стимулювальну, що додає процесу навчання професійне прискорення; виховну, що формує і розвиває професійні якості фахівця; дослідницьку, що сприяє розвитку творчого мислення майбутнього лікаря [1].

Впровадження в практику навчальних програм із збільшеною часткою самостійної роботи активно сприяє модернізації навчального процесу. Згідно 3 новими освітніми стандартами, питома вага самостійної роботи студентів має складати до 60 \% від загального навчального часу [1].

Особливої актуальності набуває раціональна організація СРС при вивченні фармакології у зв'язку зі зменшенням кількості аудиторних практичних занять та лекцій із дисципліни (табл. 1, 2).

За три навчальні роки кількість годин для практичних занять у студентів стоматологічного факультету, які навчалися за освітньо-кваліфікаційним рівнем «Спеціаліст», скоротилася в 1,6 раза зі збереженням загальної кількості годин із дисципліни. Обсяг позааудиторних годин при цьому відповідно збільшився (табл. 1). Згідно з проектом Стандарту вищої освіти МОЗ України другого (магістерського) рівня вищої освіти, у 2017 р. була складена нова програма з вивчення навчальної дисципліни «Фармакологія» освітньо-кваліфікаційного рівня «Магістр стоматології». Кількість аудиторних годин у студентів у 2018-2019 навчальному році збільшилась у 1,3 раза. Співвідношення кількості аудиторних годин до позааудиторних складає $60 \%$ проти $40 \%$.

Складніша ситуація в студентів медичного факультету (табл. 2). Згідно з типовою програмою 3 дисципліни, загальна кількість годин у них більша на 1 кредит (30 годин), а кількість аудиторних годин менша порівняно з такою на стоматологічному факультеті. За останні чотири навчальні роки кількість годин для практичних занять у студентів медичного факультету, які навчалися за освітньо-кваліфікаційним рівнем «Спеціаліст», скоротилася в 1,8 раза. Отже, все більший обсяг інформації з фармакології залишається на позаау- 
Таблиця 1. Порівняльна характеристика кількості аудиторних та позааудиторних годин з фармакології за фахом «Стоматологія» згідно з робочими програмами

\begin{tabular}{|l|c|c|c|c|c|c|}
\hline \multirow{2}{*}{ Навчальний рік } & \multirow{2}{*}{$\begin{array}{c}\text { Загальна } \\
\text { кількість } \\
\text { годин }\end{array}$} & лекції & практичні & всього & $\begin{array}{c}\text { Позааудиторні } \\
\text { години }\end{array}$ & $\begin{array}{c}\text { Співвідношення } \\
\text { аудиторні : } \\
\text { позааудиторні } \\
\text { години, \% }\end{array}$ \\
\hline \multicolumn{7}{|c|}{ Освітньо-кваліфікаційний рівень: «Спеціаліст» } \\
\hline $2014-2015$ & 180 & 20 & 100 & 120 & 60 & $62: 38$ \\
\hline $2015-2016$ & 180 & 20 & 80 & 100 & 80 & $56: 44$ \\
\hline $2016-2017$ & 180 & 20 & 64 & 84 & 96 & $47: 53$ \\
\hline $2017-2018$ & 180 & 18 & 70 & 88 & 92 & $49: 51$ \\
\hline $2018-2019$ & 180 & 28 & 80 & 108 & 72 & $60: 40$ \\
\hline
\end{tabular}

Таблиця 2. Порівняльна характеристика кількості аудиторних та позааудиторних годин з фармакології за фахом «Лікувальна справа» згідно з робочими програмами

\begin{tabular}{|c|c|c|c|c|c|c|}
\hline \multirow[b]{2}{*}{ Навчальний рік } & \multirow{2}{*}{$\begin{array}{c}\text { Загальна } \\
\text { кількість } \\
\text { годин }\end{array}$} & \multicolumn{3}{|c|}{ Аудиторні години } & \multirow{2}{*}{$\begin{array}{c}\text { Позааудиторні го- } \\
\text { дини }\end{array}$} & \multirow{2}{*}{$\begin{array}{c}\text { Співвідношення } \\
\text { аудиторні : } \\
\text { позааудиторні } \\
\text { години, \% } \\
\end{array}$} \\
\hline & & лекції & практичні & всього & & \\
\hline \multicolumn{7}{|c|}{ Освітньо-кваліфікаційний рівень: «Спеціаліст» } \\
\hline $2014-2015$ & 210 & 40 & 90 & 130 & 80 & $62: 38$ \\
\hline $2015-2016$ & 210 & 40 & 70 & 110 & 100 & $52: 48$ \\
\hline 2016-2017 & 210 & 40 & 50 & 90 & 120 & $43: 57$ \\
\hline $2017-2018$ & 210 & 38 & 50 & 88 & 122 & $42: 58$ \\
\hline \multicolumn{7}{|c|}{ Освітньо-кваліфікаційний рівень: «Магістр медицини» } \\
\hline 2018-2019 & 210 & 24 & 70 & 94 & 116 & $45: 55$ \\
\hline
\end{tabular}

диторне вивчення. Відповідно, це супроводжується зменшенням обсягу матеріалу, який розглядається на практичному занятті. 3 переходом підготовки спеціалістів другого (магістерського) рівня вищої освіти освітньо-кваліфікаційного рівня «Магістр медицини» ситуація дещо покращилась: кількість практичних занять збільшилась у 1,4 раза. Але за рахунок зменшення кількості лекційних годин у 1,6 раза загальна кількість аудиторного навантаження за останній навчальний рік суттєво не змінилась: 94 год проти 88 год у минулому році. Співвідношення кількості аудиторних годин до позааудиторних складає 45 \% проти 55 \%. Важливо зазначити, що нова типова навчальна програма 3 «Фармакології» (К., 2018) для студентів медичного факультету включає більший перелік лікарських препаратів (411 засобів), у тому числі нових (212 засобів) порівняно з минулою програмою, а також порівняно з таким переліком у навчальній програмі для студентів-стоматологів.

На сьогодні тижневі години навантаження для студентів стоматологічного факультету складають: аудиторні - 2,75 та позаудиторні (самостійна робота) - 1,75; для студентів медичного факульте- ту: аудиторні - 2,50 та позаудиторні (самостійна робота) - 2,75.

Порівняльна характеристика розподілу навчального навантаження 3 дисципліни «Фармакологія» для студентів стоматологічного та медичного факультетів представлена на рисунку 1. У студентів медичного факультету згідно з робочою навчальною програмою зменшена кількість лекційних годин на 4 \%, практичних - на $11 \%$.

Ми погоджуємося 3 думкою наших колег О. М. Олещук та співавт. (2015), що навчальна дисципліна «Фармакологія» займає особливе місце серед основних (першочергових) складових у системі вищої медичної освіти і виконує роль вагомої ланки, що поєднує теоретичні та клінічні дисципліни, знання якої забезпечують належну науково-теоретичну підготовку майбутніх лікарів і дозволяють успішно використовувати можливості фармакотерапії в клінічній практиці. Як динамічна дисципліна, фармакологія характеризується постійним оновленням і зміною інформації щодо лікарських засобів, що створює певні труднощі при вивченні її студентами. Таким чином, викладання предмета потребує науково-інноваційних підходів, 


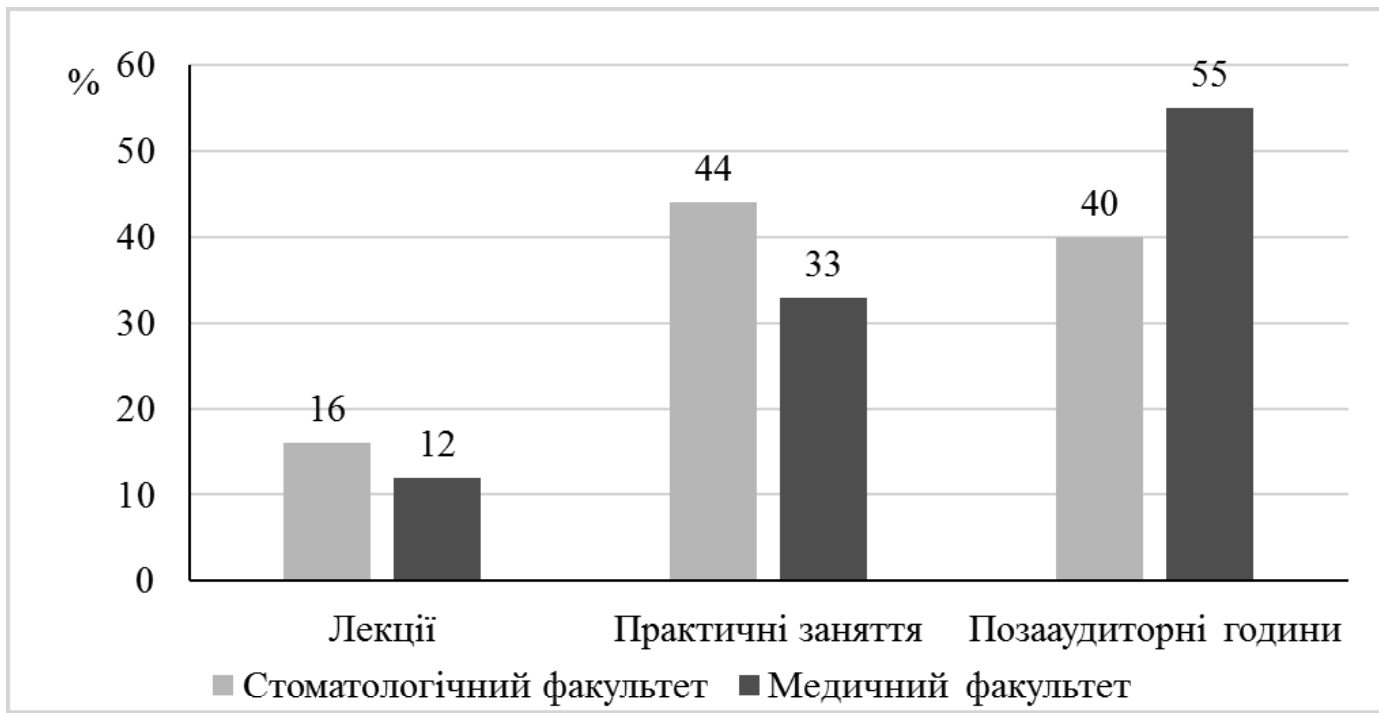

Рис. 1. Розподіл навчального навантаження з «Фармакології» у студентів стоматологічного та медичного факультетів.

пов’язаних із комп’ютеризацією і сучасними можливостями Інтернету, впровадженням віртуальних фармакологічних програм тощо [5].

Організація навчального процесу на кафедрі експериментальної та клінічної фармакології з клінічною імунологією та алергологією здійснюється за типовою навчальною програмою. СРС при вивченні фармакології складається з позааудиторної самостійної підготовки до практичних занять, проміжних контролів змістових модулів, підсумкового модульного контролю (теоретична підготовка й опрацювання практичних навичок); аудиторної самостійної роботи на практичних заняттях; індивідуальної дослідницької самостійної роботи [4].

3 метою полегшення освоєння навчальної дисципліни «Фармакологія» для студентів стоматологічного та медичного факультетів на початку року складається «Довідник студента», в якому надано інформацію щодо структури дисципліни, критеріїв оцінювання знань, матеріали для підготовки до підсумкових модульних контролів, семестрової підсумкової атестації. Активізація СРС неможлива без ефективної системи педагогічного забезпечення. За умов інформатизації освіти збільшується значення інформаційно-комунікаційної компетентності спеціалістів. Тому ми вважаємо, що впровадження в навчальний процес інформаційно-комп’ютерних технологій і цифрових освітніх ресурсів є основою підвищення якості освіти. Компетентне використання інноваційних технологій викладачем посилює педагогічний вплив на формування творчого потенціалу студента. Самостійна аудиторна робота студента на практичному занятті на кафедрі фарма- кології здійснюється під безпосереднім активним керівництвом викладача із залученням інтерактивних форм навчання. Для підвищення інтересу студентів до навчальної діяльності на практичних заняттях ми проводимо ділові ігри, дискусії, круглі столи, демонструємо набори лікарських препаратів, фотографії лікарських рослин, виконуємо експериментальні дослідження in vitro, на тваринах тощо. Цікавим для студентів $є$ використання віртуальних фармакологічних програм. Для виконання студентами позааудиторної самостійної підготовки нами розроблені методичні вказівки, в яких викладені актуальність теми, цілі навчання, теоретичні питання за темою заняття, завдання 3 медичної рецептури, тестові завдання трьох рівнів складності (авторські та з використанням бази Крок 1), ситуаційні задачі, графи логічних структур, літературні джерела. Зазначені матеріали пропонуються студентам трьома мовами: українською для вітчизняних студентів, російською та англійською для іноземних студентів. На сайті кафедри експериментальної та клінічної фармакології з клінічною імунологією та алергологією представлені методичні матеріали (методичні розробки лекцій, методичні вказівки для аудиторних занять та позааудиторної СРС). Активному опануванню інформації з предмета сприяє заповнення студентами таблиць, схем, складання ними алгоритмів щодо застосування лікарських засобів, їхніх побічних реакцій і взаємодії [4].

Самостійна робота сприяє розвитку у студентів самостійності в оволодінні теоретичними знаннями та практичними навичками, а також умінню 
самостійно використовувати знання у навчанні та практичній діяльності. Важливо при організації самостійної роботи зважати на вихідний рівень знань студентів, їх уміння планувати свою діяльність, оволодівати швидкісним читанням, пошуком інформації та її аналізом, здатністю виділяти основні положення в новій інформації та наявністю у них навичок стислого подання опрацьованого матеріалу (написання конспекту, реферату, тез; підготовка доповідей і презентацій). Ми рекомендуємо студентам для кращого запам’ятовування переводити текстовий матеріал у таблиці, схеми. Такий вид СРС сприяє систематизації теоретичної інформації. У сучасних умовах розвитку комунікацій СРС часто пов’язана з використанням комп’ютерних технологій та знанням іншої, зокрема англійської мови. Комп’ютерні мережі надають можливість студентам працювати 3 ресурсами електронних бібліотек, довідниками лікарських препаратів, електронними навчальними посібниками, міжнародними наукометричними базами, матеріалами наукових конференцій тощо.

Одним із можливих шляхів інтенсифікації СРС вбачається робота у студентському науковому товаристві. Активна участь студентів в експериментальних дослідженнях на кафедрі, майстер-класах, участь у наукових конференціях поглиблюють знання студентів з фармакології та заохочують їх до науково-дослідницької роботи.

Для належного опрацювання теоретичного матеріалу необхідно використовувати відповідну навчальну літературу. 3 цією метою студентам пропонуємо сучасні підручники та посібники 3 фармакології, видані українською та англійською мовами, в тому числі авторами або співавторами яких є викладачі нашої кафедри [7-11].

Підтвердженням професіоналізму та фахової компетентності науковців нашої кафедри слугують високі державні відзнаки. Так, Указом Президента України від 7 квітня 2017 р. № 101/2017 «Про

\section{Список літератури}

1. Аналіз ставлення студентів вищого медичного навчального закладу до самостійної роботи як виду навчальної діяльності / Н. І. Рублевська, О. А. Шевченко, Г. С. Канюка [та ін.] // Медична освіта. - 2017. № 2. - С. 64-67.

2. Досвід позааудиторної роботи зі студентами на кафедрі терапевтичної стоматології / Т. О. Петрушанко, Е. В. Ніколішина, Н. М. Іленко [та ін.] // Медична освіта. - 2018. - № 1. - С. 108-111.

3. Ждан В. М. Досвід упровадження нових форм організації навчального процесу в умовах кредитно-модульної присудження Державних премій України в галузі науки і техніки 2016 року» колектив авторів підручника «Фармакологія» (Вінниця : Нова книга, 2014. - 432 с.), серед яких і чотири співробітники кафедри - професор В. М. Бобирьов, доценти: М. М. Рябушко, Т. А. Петрова, Г. Ю. Островська, став лауреатом вказаної премії.

Висновки та перспективи подальших досліджень. Таким чином, СРС є важливою складовою навчального процесу, яка формує в студентів наполегливість, дисциплінованість, відповідальність, прагнення до вдосконалення знань і навичок, професійного росту та самоосвіти. У зв'язку з впровадженням нових навчальних програм з «Фармакології» зі збільшеною часткою позааудиторних годин, актуальним залишається підвищення ефективності СРС. Особливо це стосується студентів медичного факультету, в яких обсяг позааудиторних годин більший на 15 \% порівняно зі студентами стоматологічного факультету. Складність в оволодінні дисципліною полягає також у постійному розширенні та оновленні інформації щодо лікарських засобів. Так, у студентів медичного факультету перелік лікарських препаратів згідно з новою типовою програмою збільшено майже наполовину. Тому для оптимізації вивчення «Фармакології» викладачі кафедри підготували достатнє методичне забезпечення, постійно здійснюють консультативну допомогу студентам. 3 метою раціональної організації СРС залучаються інноваційні технології при викладанні дисципліни, інтерактивні форми навчання. Доцільними також є підготовка електронних навчальних видань та більш активне використання сучасних комп’ютерних технологій і ресурсів Інтернету.

Перспективи подальших досліджень полягають у порівняльному аналізі результатів складання ліцензійного іспиту Крок 1 з «Фармакології» серед студентів стоматологічного та медичного факультетів залежно від форми навчання відповідно освітньокваліфікаційного рівня «Спеціаліст» і «Магістр».

системи / В. М. Ждан, В. М. Бобирьов, О. В. Шешукова // Інтеграція української медичної освіти в європейський та американський медичний простір : матеріали навч.наук. конф. - Тернопіль, 2006. - С. 34-35.

4. Інноваційні технології в організації самостійної роботи студентів при вивченні фармакології / Е. Г. Колот, С. Ю. Чечотіна, Р. В. Луценко, А. Г. Сидоренко // Інноваційні технології в організації самостійної роботи студентів медичних освітніх закладів : матеріали навч.-наук. конф. з міжнар. участю, 23 березня 2017 р. - Полтава, 2017. - C. 75-76. 
5. Олещук О. М. Сучасні аспекти викладання фармакології для студентів за спеціальністю «Медико-профілактична справа» / О. М. Олещук, В. В. Черняшова, І. І. Герасимець // Медична освіта. - 2015. - № 3. - С. 63-66.

6. Оптимізація самостійної роботи студентів при вивченні фармакології / Т. О. Дев’яткіна, О. М. Важнича, Е. Г. Колот, Н. М. Дев’яткіна // Інноваційні технології в організації самостійної роботи студентів медичних освітніх закладів: матеріали навч.-наук. конф. 3 міжнар. участю, 23 березня 2017 р. - Полтава, 2017. - С. 42.

7. Фармакологія : підручник для студ. мед. ф-тів / [I. С. Чекман, Н. О. Горчакова, Л. І. Казак та ін.] ; за ред. проф. І. С. Чекмана. - 4-те вид., випр. та доопрац. Вінниця : Нова Книга, 2017. - 784 с.

\section{References}

1. Rublevska, N.I., Shevchenko, O.A., Kaniuka, H.S., Kramarova, Yu.S., Shchudro, S.A., Zaitsev, V.V., ... Dziak, M.V. (2017). Analiz stavlennia studentiv vyshchoho medychnoho navchalnoho zakladu do samostiinoi roboty yak vydu navchalnoi diialnosti [Analysis of the attitude of students of higher medical education to independent work as a type of educational activity]. Medychna osvita-Medical Education, 2, 64-67 [in Ukrainian].

2. Petrushanko, T.O., Nikolishyna, E.V., Ilenko, N.M., Popovych, I.Yu., \& Lytovchenko, I.Yu. (2018). Dosvid pozaaudytornoi roboty zi studentamy na kafedri terapevtychnoi stomatolohii [Out-of-class experience with students at the Department of Therapeutic Dentistry]. Medychna osvita Medical Education, 1, 108-111 [in Ukrainian].

3. Zhdan, V.M., Bobyrov, V.M., \& Sheshukova, O.V. (2006). Dosvid uprovadzhennia novykh form orhanizatsii navchalnoho protsesu v umovakh kredytno-modulnoi systemy [Experience of introduction of new forms of organization of educational process in conditions of credittransfer system]. Intehratsiia ukrainskoi medychnoi osvity $v$ yevropeiskyi ta amerykanskyi medychnyi prostir: materialy navch.-nauk. konf. - Integration of Ukrainian medical education into European and American medical space: materials of Educational Scientific Conference. Ternopil, 34-35 [in Ukrainian].

4. Kolot, E.H., Chechotina, S.Yu., Lutsenko, R.V., \& Sydorenko, A.H. (2017). Innovatsiini tekhnolohii v orhanizatsii samostiinoi roboty studentiv pry vyvchenni farmakolohii [Innovative technologies in the organization of students' independent work in the study of pharmacology]. Innovatsiini tekhnolohii $v$ orhanizatsii samostiinoi roboty studentiv medychnykh osvitnikh zakladiv: materialy navch.nauk. konf. z mizhnar. uchastiu - Innovative technologies in the organization of independent work of students of medical educational institutions: Materials of Educational Scientific Conference with International Participation. March, 23. Poltava [in Ukrainian].
8. Фармакологія : підручник для студ. стом. ф-тів вищих мед. навч. закладів / [І. С. Чекман, В. М. Бобирьов, В. Й. Кресюн та ін.]. - Вінниця : Нова Книга, 2014. 432 с. :іл.

9. Фармакологія : практикум / [В. М. Бобирьов, О. М. Важнича, Т. О. Дев’яткіна та ін.]. - Вінниця : Нова Книга, 2017. - 352 с.

10. Фармакологія в кросвордах : навч. посіб. / В. М. Бобирьов, Е. Г. Колот, С. Ю. Чечотіна, Т. О. Дев’яткіна. Полтава, 2017. - 150 с.

11. Pharmakology : textbook / V. Bobyrov, T. Devyatkina, O. Vazhnicha, N. Devyatkina. - 4th ed., updated. - Vinnitsya : Nova Knyha, 2018. - 552 c. : il.

5. Oleshchuk, O.M., Cherniashova, V.V., \& Herasymets, I.I. (2015). Suchasni aspekty vykladannia farmakolohii dlia studentiv za spetsialnistiu "medyko-profilaktychna sprava” [Modern aspects of pharmacology teaching for students in the specialty "medical and preventive business" ]. Medychna osvita - Medical Education, 3, 63-66 [in Ukrainian].

6. Deviatkina, T.O., Vazhnycha, O.M., Kolot, E.H., \& Deviatkina, N.M. (2017). Optymizatsiia samostiinoi roboty studentiv pry vyvchenni farmakolohii [Optimization of students' independent work in the study of pharmacology]. Innovatsiini tekhnolohii $v$ orhanizatsii samostiinoi roboty studentiv medychnykh osvitnikh zakladiv: materialy navch.nauk. konf. z mizhnar. uchastiu - Innovative technologies in the organization of independent work of students of medical educational institutions: materials of Educational Scientific Conference with International Participation. March, 23. Poltava [in Ukrainian].

7. Chekman, I.S., Horchakova, N.O., Kazak, L.I., Bielenichev, I.F., Bobyrov, V.M., Vysotskyi, I.Yu., ... Tumanov, V.A. (2017). Farmakolohiia : pidruchnyk dlia stud. med. f-tiv [Pharmacology: a textbook for students. honey. f-ts]. Chekman, I.S. (Ed.). Vinnytsia: Nova Knyha [in Ukrainian].

8. Chekman, I.S., Bobyrov, V.M., Kresiun, V.Y., Hodovan, V.V., Horchakova, N.O., Kazak, L.I., ... Riabushko, M.M. (2014). Farmakolohiia: pidruchnyk dlia stud. stom. f-tiv vyshchykh med. navch. zakladiv [Pharmacology: a textbook for students. stom. f-ts of higher honey. teach. Institutions]. Vinnytsia: Nova Knyha [in Ukrainian].

9. Bobyrov, V.M., Vazhnycha, O.M., Deviatkina, T.O., Lutsenko, R.V., \& Deviatkina, N.M. (2017). Farmakolohiia: praktykum [Pharmacology: Workshop]. Vinnytsia: Nova Knyha [in Ukrainian].

10. Bobyrov, V.M., Kolot, E.H., Chechotina, S.Yu., \& Deviatkina, T.O. (2017). Farmakolohiia v krosvordakh: navchalnyi posibnyk [Pharmacology in crossword puzzles: a textbook]. Poltava, 150. [in Ukrainian].

11. Bobyrov, V., Devyatkina, T., Vazhnicha, O. \& Devyatkina, N. (2018). Pharmakology: textbook. 4th ed., updated. Vinnitsya: Nova Knyha.

Отримано 21.10.19

Рекомендовано 04.11.19 